\title{
Protein and starch content of raw, soaked and cooked beans (Phaseolus vulgaris L.)
}

\author{
Montserrat Pujolà, Albert Farreras, Francesc Casañas *

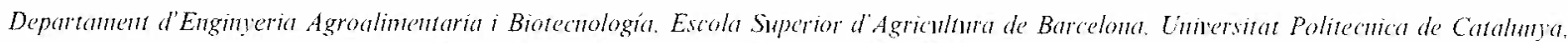 \\ Camplis Baix Llohregat. Edifici ESAB, 08860 Casteldefels. Spain
}

Received 1 December 2005; received in revised form 3 lebruary 2006: accepted 22 June 2006

\begin{abstract}
Organoleptic qualities are an important factor in the market value of legumes, especially in developed countries. Unfortunately, the molecules that have the greatest influence on the texture of beans undergo important transformations during soaking and cooking. Moreover, the extent to which these changes are linear is unknown. making uncertain the use of raw beans in chemical screenings for sensory properties. Results of our experiments show that the amount of protein and amylose present in raw beans provides a good indicator of these substances in cooked beans (correlation coefficients between raw and cooked beans $-0.91, p \leqslant 0.001$ and 0.87 , $p \leqslant 0.01$, respectively). The $\mathrm{Mg}$ content in the raw seed coat also shows a strong correlation with that found in the cooked seed coat $(r=0.86, p \leqslant 0.01)$. The correlations found for the other traits are weaker, indicating that the evaluation of raw samples is not predictive of the findings in cooked beans.

(C) 2006 Elsevier Ltd. All rights reserved
\end{abstract}

Keywords: Conmon beans: Soaking: Cooking: Chemical changes: Texture prediction in cooked beans

\section{Introduction}

Dry beans have recovered prestige in the diets of developed countries. This is due, in part, to health problems related to meat consumption, as well as the discovery of the benefits of legumes in the diet and the protection they afford against colon disease (Champ, 2001: Hangen \& Bennink, 2003: Lee, Prosky, \& DeVries, 1992; Mathres, 2002).

Consumers in these wealthy countries seek high organoleptic qualities. Unfortunately, breeders and producers in the second half of the twentieth century disregarded the obtainment and promotion of varieties with high organoleptic qualities. Consequently, most information available about the properties of legumes in general and beans in particular refers to their production and nutrition-related chemical composition (Broughton. Hernández, Beebe,

\footnotetext{
* Corresponding atuthor. Tel.: +34935521215 : fax -34935521121

E-mail address: francesc casanasoupcedu (F. Casinas)
}

0308-8146/S - see front matter 2006 Elsevier Ltd. All rights reserved. doi: $10.1016 / j$ foodchem.2006.06.039
Gepts, \& Vanderleyden, 2003). The lack of information about sensory characteristics makes the objective description of materials and their genetic improvement difficult from this perspective.

One of the most highly appreciated aspects of beans in gastronony is their texture, although the main chemical components for this characteristic are uncertain for both the seed coat and the cotyledon. Uronic acids seem to play a role in the perception of the seed coat (Casanas, Pujola, Bosch. Sánchez, \& Nuez, 2002; Wang. Chang, \& Grafton. 1988), as does the content of $\mathrm{Ca}$ and $\mathrm{Mg}$ (Quenzer, Fuman. \& Burns, 1978). The protein and starch (with its components) content must contribute to the texture, considering their quantitative importance in the seed, their properties in other foods (Champagne, Bett-Garber, McClung, \& Bergman, 2004; Ong \& Blanxhard, 1995; Park, Kim, \& Kim. 2001; Ramesh, Bhattacharya, \& Mitchell, 2000) and similar findings in beans (Pujolia et al., 2004).

At present, we need trained panelists working with cooked beans to evaluate the sensory properties of beans. 
Both the method of evaluation (sensory panel) and the state of the product (cooked) place severe limits on the number of samples that can be evaluated. For this reason, it would be helpful to handle chemical or instrumental approximations, to describe materials objectively, in order to evaluate the genetic and environmental influences on sensory qualities and thus enable selection. Eliminating the need for cooking would also simplify the evaluation of these traits but the cooking process has been shown to affect chemical parameters such as fibre (Kutos, Golob, Kac, \& Plestenjak, 2003; Rehman \& Shah, 2004).

As mentioned above, there are some indications regarding the factors responsible for texture in beans. To estimate the sensory value of the cooked beans from the concentration of some of these components would be very valuable. Unfortunately, limited information is available on this subject (Casañas et al., 2002; De Almedia Costa, QueirozMonici, Pissini, \& de Oliveira, 2004; Hosfield \& Uebersax, 1980; Hosfield, Uebersax, \& Isleib, 1984).

Against this background, our aim is to determine to what extent the chemical composition of raw or soaked beans is a reliable indicator of their chemical composition after cooking, and thereby determine whether the chemical composition of raw and/or soaked beans would be useful in the evaluation of their texture after cooking.

\section{Material and methods}

\subsection{Genetic material}

The Spanish landraces (traditional varieties) Planchada, Tolosa, Faba, Genoll de Crist, Castellfollit del Boix and Ganxet, and the American variety Midland (Navy market class (Santalla, De Ron, \& Voysest, 2001)) were used. Planchada is white and flat, has a $57 \mathrm{~g} / 100$ seed weight, and belongs to the Large Great Northern market class (Santalla et al., 2001), Tolosa is dark and rounded, has a $40 \mathrm{~g} / 100$ seed weight, and belongs to the Negro Brillante market class (Santalla et al., 2001), Faba is white and elongated, has a $93 \mathrm{~g} / 100$ seed weight and belongs to the Faba market class (Santalla et al, 2001), Genoll de Crist is white, with a brown spot around the hilum, and rounded, has a $39 \mathrm{~g} / 100$ seed weight, and belongs to the Rounded Caparron market class (Santalla et al., 2001), Castellfollit del Boix is white and flat, has a $44 \mathrm{~g} / 100$ seed weight, and belongs to the Great Northern market class (Santalla et al., 2001), and Ganxet is white, flat and kidney shaped, has a $52 \mathrm{~g} / 100$ seed weight (Bosch, Casanas, Sánchez, Pujola, \& Nuez, 1998), and belongs to the Hook market class (Santalla et al., 2001).

All varieties had been shown to be clearly different from a sensory perspective (Casañas et al., 2004; Pujolà et al., 2004) and enjoy great prestige in gastronomic and/or industrial uses. Each variety was cultivated in Spain in the region where it most fully develops its organoleptic traits. For the Ganxet variety, samples from three different locations within the most favourable growing area for this bean were used (Ganxet 10, Ganxet 11 and Ganxet 53). Previous experiments (Casañas et al. 2004; Pujolà et al., 2004) have shown that these varieties exhibit a wide range of variation for the texture of the seed coat and cotyledon, as well as for their chemical composition.

\subsection{Chemical analyses}

On the basis of previous experiments (Pujolà et al., 2004), as well as those of other authors with beans or different grains (Champagne et al., 2004; Ong \& Blanxhard, 1995; Park et al., 2001; Ramesh et al., 2000) the most important molecules involved in texture are taken to be protein, starch (amylose, amylopectine), and seed coat $\mathrm{Ca}$ and $\mathrm{Mg}$. Resistant starch was also analyzed because it is considered to be a fermentable component (together with the raffinose group) and therefore related to the protective capacity attributed to beans on the colonic mucosa.

\subsubsection{Samples and sample preparation}

The nine samples were analyzed in the following states: raw (full seed), soaked (full seed and seed coat) and cooked (full seed and seed coat). Raw seeds of each type were dried to constant weight and ground to pass through the $0.5 \mathrm{~mm}$ screen of a mill (Laboratory Mill 3100 , Perten).

Another fraction of each sample was soaked for $24 \mathrm{~h}$ at $20^{\circ} \mathrm{C}(2500 \mathrm{ml}$ of tap mineral water were added to $500 \mathrm{~g}$ of bean seed). After soaking, the seed coats (episperm) of randomly chosen seeds were separated from the rest of the seed (endosperm plus embryo) and were dried to constant weight allowing calculation of the ratio of the seed coat weight to the total weight (seed coat proportion, as a percentage). Both seed coat and a sample of soaked full seed were then separately milled.

A fraction of the soaked seeds was cooked in low mineralized water until the optimum state for consumption was reached. Cooked beans were processed like soaked beans, to obtain milled samples of seed coat and full seed.

The moisture content of all fractions was determined by gravimetric heating $\left(65^{\circ} \mathrm{C}, 48 \mathrm{~h}\right)$ in a convection oven.

\subsubsection{Crude protein was determined using the Kjeldahl method}

(AOAC, 1990), quantifying the amount of nitrogen by selective ammonium electrode. Crude protein content was then calculated as $\% \mathrm{~N} \times 6.25$.

\subsubsection{Starch content was determined using the Official AOAC (1997)}

Glucose was determined by HPLC chromatography. The total starch was calculated as glucose $\times 0.9$

\subsubsection{Amylose and amylopectin}

Amylose content was analyzed using the methodology proposed by Juliano et al. (1981). The complex coloration amylase/iodide was determined using a UV/Visible spectrophotometer $(i=620 \mathrm{~nm})$. The amylopectin content 
was calculated as the difference between the starch content and amylose content.

\subsubsection{Resistant starch analysis}

Resistant starch content was analyzed using the methodology proposed by Goñi, Garcia-Diz, Mañas, and SauraCalixto (1996). The main steps were: incubation of the samples $\left(40^{\circ} \mathrm{C}, 60 \mathrm{~min}, \mathrm{pH} 1.5\right)$ with pepsin $(10 \mathrm{mg} / \mathrm{mL})$ to remove protein, incubation $\left(37^{\circ} \mathrm{C}, 16 \mathrm{~h}, \mathrm{pH}\right.$ 6.9) with $\alpha$-amylase $(1 \mathrm{~mL}, 40 \mathrm{mg} / \mathrm{mL})$ to hydrolyze digestible starch, treatment of the residues with basic medium to solubilize resistant starch, and incubation $\left(60^{\circ} \mathrm{C}, 45 \mathrm{~min}, \mathrm{pH} 4.5\right)$ with amyloglucosidase $(140 \mathrm{U} / \mathrm{mL})$ to hydrolyze the solubilized resistant starch. The glucose was determined by HPLC.

\subsubsection{Ca and $\mathrm{Mg}$}

The analysis was performed on the ash extract (dissolution in $2 \mathrm{M} \mathrm{HNO}_{3}$ ). Ca and $\mathrm{Mg}$ were quantified by atomic spectrophotometry.

\subsection{Statistical analysis}

The results of the analyses for each chemical variable were determined according to the linear model:

$\mathrm{x}_{i j k}=\mu+\mathrm{v}_{i}+\mathrm{s}_{j}+\mathrm{v}_{i} \mathrm{~s}_{j}+\varepsilon_{i j k}$,

in which $v$ is the variety effect, s the state (raw, soaked, cooked) effect and $\varepsilon$ the residual effect.

An analysis within each state was also performed according to the model:

$\mathrm{x}_{i j}=\mu+\mathrm{v}_{i}+\varepsilon_{i j}$,

Pearson's coefficient was used to calculate the correlations between the values of the different states. All statistical analyses were performed using the SAS statistical package (SAS Institute, 1985).

\section{Results and discussion}

\subsection{Significance of the variation}

Variety and state effects and their interaction showed highly significant differences $(p \leqslant 0.0001)$ for all traits except seed coat $\mathrm{Mg}(p \leqslant 0.12)$. As stated above, the varieties selected have considerable differences, with respect to sensory characteristics; therefore, these differences in the chemical components, presumably responsible for sensory traits, were expected.

The difference between states was previously reported by Phirke, Chavan, Hadgam, and Salunkhe (1982), with respect to protein, and by Rehman, Salariya, and Zafar (2001) with respect to starch. The losses are attributable to solubilization and hydrolysis by both enzymes and heat.

More interesting is the interaction between variety and state, significant for all traits. These findings indicate that the chemical composition of the raw bean will not always be a good indicator of the chemical composition of the bean after soaking and cooking.

\subsection{Loss of solids during processing}

More solids are lost during soaking than during cooking (Table 1). At the end of the soaking and cooking process, the varieties with the smallest loss have lost approximately $16^{1 \%} / n$ of their solids contents, whereas those with the greatest loss have lost approximately $22 \%$ (Table 1). Losses in each process show significant trends, but an important variety effect is also present (Table 1).

The concentration of protein tends to rise, while the concentration of amylose remains constant during the process. That of amylopectin and starch drop sharply, as does the concentration of resistant starch (Table 2). These general trends are logical, as amylopectin is solubilized and lost from the bean seed, which in turn affects the concentration of starch. The concentration of resistant starch rises at first because it is not altered much by soaking, while other components are solubilized. Afterwards, part of the resistant starch is modified by heat during cooking and is converted into digestible starch. Cooks have traditionally taken advantage of the water in which beans were cooked, to enhance other dishes (soups, bases for sauces or other dishes, etc.). In other cases, the cooking water is not drained from the cooked beans and is a constituent of the dish (Fabada Asturiana, Cassoulet, Pasta e Faggioli, etc.).

\subsection{Variation of the components in the whole bean in each variety and stage}

As not all of the beans were cultivated at the same site (each variety was cultivated in the place where it would achieve its characteristic organoleptic traits best), the variation we recorded was partly due to the variety effect and partly to the effect of the site of cultivation and interaction. The objective of this study was not to evaluate the properties of the different varieties, but rather to examine the

Table 1

Percentage of loss of solids for each variety during soaking and cooking, and accumulated

\begin{tabular}{lccl}
\hline Variety & $\begin{array}{c}\text { "/ Loss during } \\
\text { soaking }\end{array}$ & $\begin{array}{l}\text { "/i Loss } \\
\text { during } \\
\text { cooking }\end{array}$ & $\begin{array}{l}\text { "/a Loss during } \\
\text { soaking + cooking }\end{array}$ \\
\hline Planchada & 9.6 & 8.3 & 17.9 \\
Tolosa & 12.4 & 4.6 & 17.0 \\
Faba & 8.7 & 12.2 & 20.9 \\
Genoll de Crist & 12.1 & 9.8 & 21.9 \\
Navy Midland & 13.8 & 6.3 & 20.1 \\
Castellfollit del Boix & 13.1 & 7.2 & 20.3 \\
Ganxet C53 & 9.8 & 6.3 & 16.1 \\
Ganxet Ci0 & 9.3 & 6.8 & 16.5 \\
Ganxet Cl1 & 8.9 & 8.4 & 17.3 \\
Mean loss & $10.8 \pm 0.7$ & $7.8 \pm 0.8$ & $18.7 \pm 0.7$ \\
\hline
\end{tabular}


Table 2

Differences between varieties in the content of each component at raw (a). soaked (b), and cooked states (c)

\begin{tabular}{|c|c|c|c|c|c|c|}
\hline Variety & Protein & Amylose & Amylopectin & Starch & Aml/amp & Resistant starch \\
\hline \multicolumn{7}{|l|}{ (a) Raw } \\
\hline Castellfollit & $320 a^{a}$ & $125 \mathrm{~d}$ & $319 b$ & $444 d$ & $0.39 \mathrm{~d}$ & $253 b c$ \\
\hline Faba & $247 d$ & $158 a$ & $354 a$ & $511 \mathrm{~b}$ & $0.44 \mathrm{bc}$ & $269 \mathrm{~b}$ \\
\hline Ganxet 10 & $283 c$ & $134 c$ & $322 b$ & $456 \mathrm{c}$ & $0.42 \mathrm{bcd}$ & $227 d$ \\
\hline Ganxet 11 & $281 \mathrm{c}$ & $128 \mathrm{~cd}$ & $286 \mathrm{c}$ & $414 \mathrm{e}$ & $0.44 \mathrm{bc}$ & $235 \mathrm{~cd}$ \\
\hline Ganxet 50 & $296 \mathrm{~b}$ & $150 \mathrm{~b}$ & $310 b$ & $459 c$ & $0.49 a$ & $253 b c$ \\
\hline Genoll de Crist & $246 d$ & $144 \mathrm{~b}$ & $356 a$ & $500 \mathrm{~b}$ & $0.41 \mathrm{~d}$ & $214 d$ \\
\hline Navy & $287 \mathrm{c}$ & $146 b$ & $359 a$ & $505 b$ & $0.4 \mathrm{lcd}$ & $229 \mathrm{~cd}$ \\
\hline Planchada & $237 \mathrm{de}$ & $147 \mathrm{~b}$ & $357 \mathrm{a}$ & $503 b$ & $0.42 \mathrm{bcd}$ & $253 b c$ \\
\hline Tolosia & $234 \mathrm{e}$ & $162 \mathrm{a}$ & $361 \mathrm{a}$ & $523 a$ & $0.45 b$ & $305 a$ \\
\hline \multicolumn{7}{|l|}{ (b) Soaked } \\
\hline Castellfollit & $307 a$ & $131 \mathrm{~d}$ & $238 \mathrm{bc}$ & $369 c$ & $0.55 \mathrm{~d}$ & $68 \mathrm{e}$ \\
\hline Faba & 247 de & $172 a$ & $237 \mathrm{bc}$ & $409 \mathrm{~b}$ & $0.73 \mathrm{abc}$ & $24 g$ \\
\hline Ganxet 10 & $279 \mathrm{~b}$ & $156 \mathrm{bc}$ & $193 d$ & $350 \mathrm{c}$ & $0.81 \mathrm{ab}$ & $70 \mathrm{e}$ \\
\hline Ganxet 11 & $272 b c$ & $158 \mathrm{bc}$ & $197 d$ & $355 \mathrm{c}$ & $0.81 a b$ & $97 d$ \\
\hline Ganxet 50 & $259 \mathrm{~cd}$ & $150 \mathrm{c}$ & $201 \mathrm{~d}$ & $350 c$ & $0.75 \mathrm{ab}$ & $163 \mathrm{~b}$ \\
\hline Genoll de Crist & $265 b c$ & $153 b c$ & $265 b$ & $417 \mathrm{~b}$ & $0.58 \mathrm{~d}$ & $22 \mathrm{~g}$ \\
\hline Navy & $280 \mathrm{~b}$ & $169 a$ & $233 c$ & $402 b$ & $0.73 \mathrm{abc}$ & $58 \mathrm{f}$ \\
\hline Planchada & $223 . f$ & $161 \mathrm{~b}$ & $257 b c$ & $418 \mathrm{~b}$ & $0.63 \mathrm{bcd}$ & $232 a$ \\
\hline Tolosal & $243 e$ & $172 \mathrm{a}$ & $287 a$ & $459 \mathrm{a}$ & $0.6 \mathrm{~cd}$ & $123 c$ \\
\hline \multicolumn{7}{|l|}{ (c) Cooked } \\
\hline Castellfollit & $360 \mathrm{a}$ & $120.1 e$ & $92.8 \mathrm{c}$ & $213 e$ & $1.31 \mathrm{bc}$ & $52 \mathrm{c}$ \\
\hline Faba & $284 d$ & $157.9 \mathrm{~b}$ & $128 \mathrm{ab}$ & $287 \mathfrak{a}$ & $1.23 b c$ & $25 \mathrm{e}$ \\
\hline Ganxet 10 & $289 \mathrm{~d}$ & $145.2 c$ & $105 b c$ & $25 \mathrm{lcd}$ & $1.38 \mathrm{bc}$ & $58 \mathrm{~b}$ \\
\hline Ganxet 11 & $312 \mathrm{c}$ & $134.5 \mathrm{~d}$ & $116 a b$ & $250 \mathrm{~cd}$ & $1.16 \mathrm{c}$ & $43 d$ \\
\hline Ganxet 50 & $325 b$ & $141 c$ & $112 \mathrm{ab}$ & $253 c$ & $1.26 \mathrm{bc}$ & $78 \mathrm{a}$ \\
\hline Genoll de Crist & $291 \mathrm{~d}$ & $156.2 \mathrm{~b}$ & $118 \mathrm{ab}$ & $274 \mathrm{~b}$ & $1.33 b c$ & $21 f$ \\
\hline Navy & $330 \mathrm{~b}$ & $151.5 b$ & $120 \mathrm{ab}$ & $27 ! b$ & $1.2 b c 7$ & $53 c$ \\
\hline Planchada & $267 \mathrm{e}$ & $153.7 \mathrm{~b}$ & $102 b c$ & $256 c$ & $1.51 \mathrm{~b}$ & $25 \mathrm{e}$ \\
\hline Tolosa & $284 d$ & $167.1 \mathrm{a}$ & 71.80 & $239 \mathrm{~d}$ & $2.34 a$ & $75 d$ \\
\hline \multicolumn{7}{|c|}{$\begin{array}{l}\text { (d) At each state and global } \\
\text { State }\end{array}$} \\
\hline Raw & $270 \mathrm{~b}^{\mathrm{at}}$ & $144 c$ & $326 a$ & $480 \mathrm{a}$ & $0.43 c$ & $24 a$ \\
\hline Soaked & $264 c$ & $158 a$ & $234 \mathrm{~b}$ & $392 b$ & $0.69 \mathrm{c}$ & $95 \mathrm{~b}$ \\
\hline Cooked & $305 a$ & $147 b$ & $107 c$ & $255 \mathrm{c}$ & $1.42 \mathrm{c}$ & $48 \mathrm{c}$ \\
\hline Mean content & $280 \pm 13$ & $150 \pm 4$ & $236 \pm 66$ & $376 \pm 65$ & $0.85 \pm 0.30$ & $56 \pm 21$ \\
\hline
\end{tabular}

Average of each component at each state and global mean (c).

a Values expressed in $\mathrm{g}$ per $\mathrm{kg}^{-1}$ of dry matter. Mean values followed by the same letter are not significantly different $p \leqslant 0$.05 according to NewmanKeuls test.

behavioural trends of particular phenotypes that we consider to be models.

As seen in the overall ANOVA, significant differences were found for all traits and states. However, the variation of these values is not linear and the degree of linearity varies from one trait to another (Table 2). The proportions of protein and amylose in the different varieties varies little during soaking and cooking and the rank order of the varieties for these traits is maintained. Conversely, amylopectin, starch and resistant starch undergo noteworthy changes (Table 2).
The correlation for each variable between the different states is in general not significant (Table 3). Only protein content and amylose content show a high correlation between the raw and cooked states (the most interesting correlation for a breeding programme).

Protein has a similar behaviour in all of the varieties, except Genoll de Crist in the soaked state, although this exception does not affect the raw-cooked relationship (Fig. 1). A similar behaviour is observed with respect to amylose (Fig. 1), as was clear from the coefficients of correlation.

Table 3

Correlations between the content of the different components at the different states

\begin{tabular}{lllllrr}
\hline State & Protein & Amylose & Amylopectin & Starch & Aml/amp & Resistant starch \\
\hline Raw cooked & $0.908^{\mathrm{a}}$ & $0.87^{\mathrm{a}}$ & -0.11 & 0.479 & 0.155 & 0.3939 \\
Soaked cooked & $0.84^{\mathrm{a}}$ & $0.85^{\mathrm{a}}$ & -0.47 & 0.233 & -0.43 & 0.2401 \\
\hline a $p \leqslant 0.01$ & & & & &
\end{tabular}



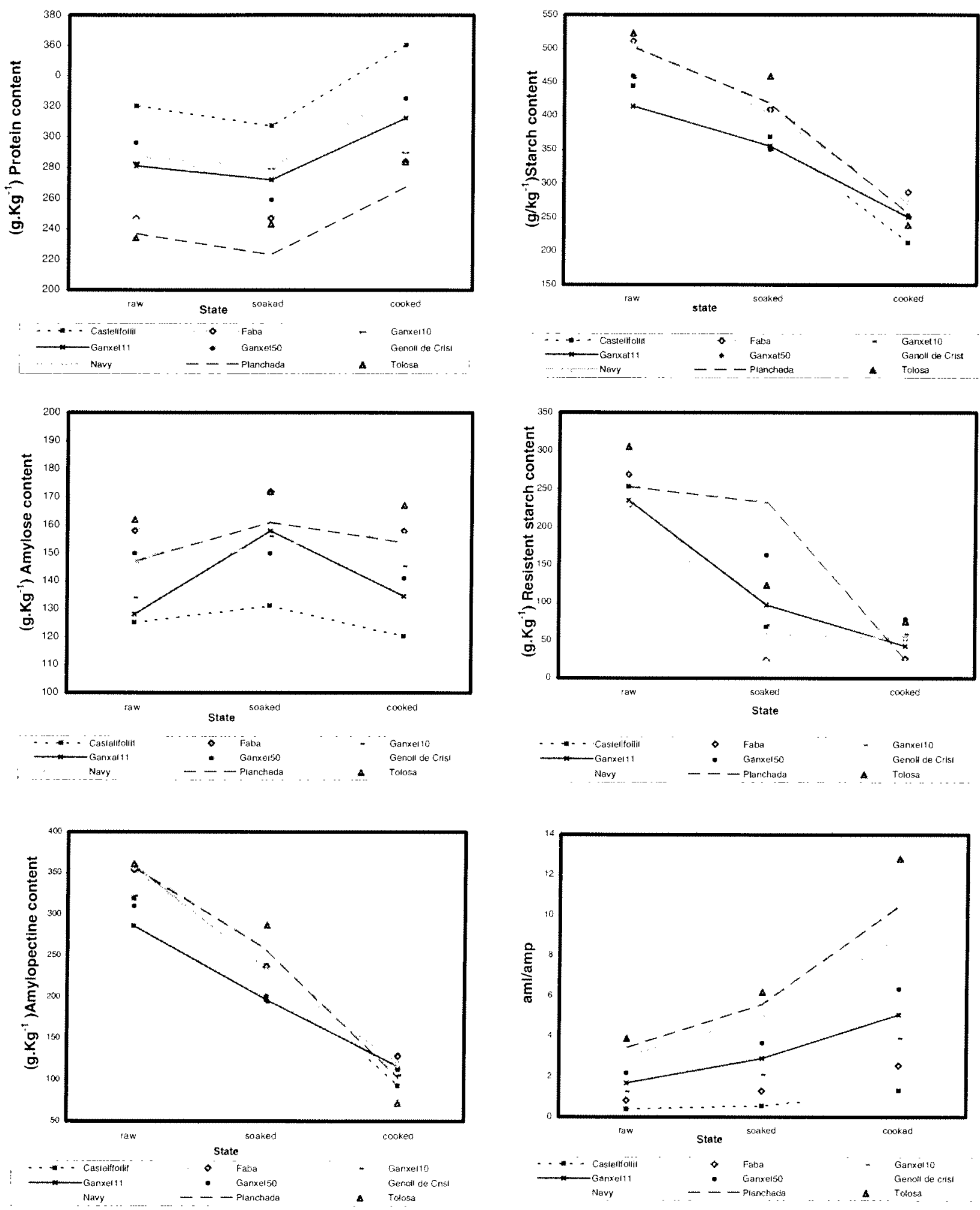

Fig. 1. Evolution of the different components of the bean in each state and variety.

With respect to the evolution of starch, there are two varieties, Castellfollit and Tolosa, that exhibit behaviours different from the rest. These varieties lose a greater pro- portion of their starch during the cooking process (Fig. 1). If we omit these two varieties from the correlations, the correlation coefficient between raw and cooked 
states is $0.70(p \leqslant 0.07)$. There seem to be two patterns of behaviour for the loss of starch: 1. Gradual loss during soaking and cooking, which applies to most of the varieties, and 2, marked loss during cooking, which applies to Castellfollit and Tolosa.

Amylopectin is the component that exhibits the least consistent relationship between the three states. Given its chemical structure, one would expect this erratic behavior (Rosin, Lajolo, \& Menezes, 2002). The combined correlation of all of the varieties is very low and non-significant $(r=-0.11, p \leqslant 0.76)$; however, as in the case of starch, it is also possible to discern two patterns of behaviour (Fig. 1). Whereas Castellfollit, Ganxet and Tolosa show slight loss (the correlation coefficient between raw and cooked, considering the five entries is -0.93 , significant at $p \leqslant 0.03$ ), Faba, Navy, Genoll de Crist and Planchada show a less pronounced and more irregular loss (the correlation coefficient between raw and cooked for this group of varieties is $-0.44, p \leqslant 0.56$ ).

The ratio of amylase to amylopectin ( $\mathrm{aml} / \mathrm{amp}$ ) shows a non-significant correlation between the raw and cooked states, as a consequence of the overall erratic behavior of starch and especially of amylopectin.

The evolution of the content of resistant starch is practically parallel in all of the varieties except Planchada (Fig. 1), which shows a very slight loss during soaking and a substantial loss during cooking. The nature of resistant starch is highly variable, and its conversion to conventional starch is partly due to enzymatic action and partly due to heat. As is shown in Fig. 1, the greatest transformation occurs during soaking in the majority of the samples.

\subsection{Variation of the percentage of seed coat and $\mathrm{Ca}$ and $\mathrm{Mg}$ concentrations}

The estimations of the proportion of seed coat with respect to the cotyledon can only be carried out in the soaked and cooked states, as the two parts cannot be separated in dry beans. Navy and Tolosa were found to have the highest proportions, together with Genoll de Crist. Paradoxically, these beans are the roundest in shape, which means that they would be expected to have a lower proportion of seed coat than beans with shapes that deviate more from the spherical (Table 4). Therefore, we presume that these varieties have thicker and/or more dense seed coats.

During the cooking process, the seed coat loses less substance than the cotyledon, so that the proportion of seed coat is higher in cooked beans. The variations are, however, very random (Table 4) and our experiments do not allow us to say whether they are due to differential loss of the components of the seed coat or to differential loss of the cotyledon content. Given the chemical composition of the seed coat, the differences seem more likely to be attributable to differential losses of the cotyledon content (Table 2), especially starch. The correlation between the values for the percentage of seed coat in the soaked state and in the cooked
Table 4

Variation of the seed coat proportion and its $C a$ and $M g$ content during soaking and cooking in each variety

\begin{tabular}{|c|c|c|c|}
\hline Variety & Seed coat proportion & $\mathrm{Ca}$ & $\mathrm{Mg}$ \\
\hline \multicolumn{4}{|c|}{ (a) Soaked seed roal } \\
\hline Castellfollit & $61.3 b c^{i t}$ & $34.2 \mathrm{a}$ & $4.9 \mathrm{ef}$ \\
\hline Faba & $56.4 \mathrm{~cd}$ & $12.0 \mathrm{~d}$ & $4.6 \mathrm{f}$ \\
\hline Ganxet 10 & $50.0 \mathrm{~d}$ & $22.6 \mathrm{bc}$ & $9.2 \mathrm{~b}$ \\
\hline Ganxet11 & $54.3 \mathrm{~cd}$ & $24.0 \mathrm{bc}$ & $10.5 \mathrm{a}$ \\
\hline Ganxet 50 & $53.5 \mathrm{~cd}$ & $25.7 \mathrm{~b}$ & $7.8 \mathrm{c}$ \\
\hline Genoll de Crist & $65.3 \mathrm{ab}$ & $19.5 c$ & $3.3 \mathrm{~g}$ \\
\hline Navy & $72.9 \mathrm{a}$ & $19.5 \mathrm{c}$ & $5.9 \mathrm{~d}$ \\
\hline Planchada & $54.0 \mathrm{~cd}$ & $23.5 b c$ & $5.3 \mathrm{e}$ \\
\hline Tolosa & $70.4 a$ & $13.5 \mathrm{~d}$ & $4.5 \mathrm{f}$ \\
\hline Mean value & $59.8 \pm 2.7$ & $21.6 \pm 2.2$ & $6.2 \pm 0.8$ \\
\hline \multicolumn{4}{|c|}{ (b) Cooked seed roat } \\
\hline Castellfollit & $132.5 \mathrm{c}$ & $12.9 \mathrm{a}$ & $6.9 \mathrm{~d}$ \\
\hline Faba & $131.2 \mathrm{c}$ & $9.6 \mathrm{bcd}$ & $5.9 \mathrm{e}$ \\
\hline Ganxet 10 & $154.0 \mathrm{~b}$ & $11.0 \mathrm{bc}$ & $7.7 \mathrm{c}$ \\
\hline Ganxet I I & $131.7 \mathrm{c}$ & $6.4 \mathrm{de}$ & $8.2 \mathrm{~b}$ \\
\hline Ganxet 50 & $139.7 \mathrm{c}$ & $11.0 \mathrm{bc}$ & $8.4 a$ \\
\hline Genoll de Crist & $141.7 \mathrm{~b}$ & $5.5 \mathrm{e}$ & $4.9 \mathrm{~g}$ \\
\hline Navy & $121.7 \mathrm{~d}$ & $8.6 \mathrm{cde}$ & $6.9 \mathrm{~d}$ \\
\hline Planchada & $104.4 \mathrm{e}$ & $20.2 a$ & $5.7 f$ \\
\hline Tolosa & $162.3 \mathrm{a}$ & $7.5 \mathrm{cde}$ & $4.8 \mathrm{~g}$ \\
\hline Mean value & $135.5 \pm 5.7$ & $10.3 \pm 1.5$ & $6.6 \pm 0.5$ \\
\hline
\end{tabular}

"Values are expressed in g per $\mathrm{kg}{ }^{\prime}$ of dry matter. Mean values followed by the same letter are not significantly different $p \leqslant 0.05$ according to Newnan-Keuls test.

state is not significantly different from zero at $p \leqslant 0.05$ $(r=0.13)$.

With respect to $\mathrm{Ca}$, the correlation between the values observed in the soaked state and in the cooked state is $0.38(p \leqslant 0.32)$. This low correlation is partly due to the different behaviour of Faba, Tolosa and Planchada, with respect to the rest of the varieties (Table 4). In fact, if we omit these three varieties from the analysis, the correlation between the soaked and cooked states is $0.73(p \leqslant 0.10)$, and it is $0.96(p \leqslant 0.20)$ for these three varieties considered separately. There seem to be two different patterns of $\mathrm{Ca}$ loss (one in which the Ca concentration decreases 2.5-fold, and the other with a 1.5 -fold decrease).

Very little variation in magnesium is seen. It drops slightly (Table 4) but this is a linear decrease as the correlation between the soaked and cooked states is 0.86 $(p \leqslant 0.003)$.

\subsection{Variety and environmental effects}

It seems that the variety effect is very important for describing the behaviour of the materials, although the absolute values are influenced by the growing environment (Tables 2 and 4). The three Ganxet samples, which correspond to the same germplasm cultivated at three different sites, are in the same significance group or at most in the contiguous one for each state. The exception is resistant starch, which seems to behave somewhat more irregularly. 


\section{Conclusions}

There is a very pronounced loss of dry material during soaking and cooking. Although there is evidence that some of these losses are desirable (oligosaccharides of the raffinose family), it is also true that the cooking liquid is also often used to prepare dishes. From the nutritional viewpoint, it would be highly recommendable to skip the soaking stage or to retain the same water for soaking and cooking.

The analysis of protein and amylose content in the dry bean provides a good indication of their content in the cooked bean (correlation coefficients of $0.91 \quad(p \leqslant 0.001)$ and 0.87 ( $p \leqslant 0.01$ ), respectively).

As for starch content, the correlation between the raw and cooked states is near the limits of acceptability, if we omit the varieties Castellfollit and Tolosa from the analysis. It seems that some varieties have a greater tendency to lose starch during processing, especially during cooking.

As expected, the losses in amylopectin and starch contents were unpredictable, and the concentration of these components in raw beans is not a good indicator of what will be found in the cooked product. Although we were able to establish some differential patterns of evolution, these findings are of little use for predictions, as it would be impossible to know a priori which pattern of evolution to apply for a given sample.

Traits related to the seed coat have proven to be very erratic, and only $\mathrm{Mg}$ shows a strong correlation between its concentration in raw and cooked materials.

From the perspective of the breeder, faced with a large number of samples, it is useful to know that protein, amylose, $\mathrm{Mg}$ and, to a certain extent, starch estimated in raw beans provide a sufficient indication of the content of these molecules in the cooked product. To the degree that the importance of these three molecules in the determination of texture is confirmed, analyzing them in the raw bean will be useful, especially so as to discard materials expected to have undesirable textures.

\section{References}

AOAC (1990). Official methods of analysis (15th ed.). Arlington. VA, USA: The Association of Official Analysis Chemists.

AOAC (1997). Official methods of analysis (20th ed.). Arlington, VA. USA: The Association of Official Analysis Chemists.

Bosch. L.. Casañas, F. Sánchez, E., Pujolà, M.. \& Nuez, F. (1998). Selection L67. a pure line with true seed type of the Ganxet common beawn (Phaseolus miguris L.). HartScience, 33, 905-906.

Broughton, W. J., Hernández, G., Beebe, S., Gepts, P., \& Vanderleyden, J. (2003). Beans (Phaseolis spp.) model food legumes. Plant and Soil, 252 , $55-128$.

Casañas, F., Pujola, M. Bosch, L., Sánchez, E, \& Nuez, F. (2002). Chemical basis for the low sensory perception of the Ganxet bean (Phaseohs tulgaris L.) seed coat. Joumal of the Science of Food and Agriculture, 82, 1282-1286.

Casañas, F., Romero del Castillo, R., Pujolì, M., Bosch, L., Florez, A., Almirall, A., et al. (2004). Variability in the texture of Catalan landraces of common bean (Phaeolhs rudgaris L.): sensory and chemical approach. In J. Vollmann, H. Grausgnuber, \& P. Reuckenb- aure (Eds.), Genetic rurionion for plant breeding (pp. 419-422). Tulln: Eucarpia Congress.

Champ, M. M. J. (2001). Benefits of pulses in human diet. In Proceedings of the fourth European conference on grain legumes, Cracow. Poland, AEP editors (pp. 109-113). Paris

Champagne, E. T., Bett-Garber. K. L. McClung, A. M. \& Bergman, C. (2004). Sensory characteristics of diverse rice cultivars its influenced by genetic and envirommental factors. Cereal Che'ristry, 81, 237-243.

De Almedia Costa, G. E., Queiroz-Monici, K. S., Pissini, S. M., \& de Oliveira, A. C. (2004). Chemical composition, dietary fibre and resistant starch contents of raw and cooked pea, common bean, chickped and lentil legumes. Food Chemistry, 94, 327-330.

Gonii, I., Garcia-Diz, L., Mañas, E., \& Saura-Calixto, F. (1996). Analysis of resistant starch: a method for foods and foods products. Food Chemistry, 56, 445-449.

Hangen, L. A., \& Bennink. M. R. (2003). Consumption of black beans and navy beans (Phoseolus anlgaris) reduced azoxymethane-induced colon cancer in rats. Nutrition and Concer. 44, 60-65.

Hosfield, G. L., \& Uebersax, M. A. (1980). Variability in physicochemical properties and nutritional components of tropical and domestic dry bean gemplasm. Journal of the Anerican Society of Horticultural Science, 105, 246-252.

Hosfield, G. L., Uebersax, M, A., \& Isleib, T. G. (1984). Seasonal and genotypic effects on yield and physic-chemical seed characteristics related to food quality in dry, edible beans. Journal of the American Society of Horticultwal Science, 109, 182-189.

Juliano, B. O., Perez, C. M., Blakeney, A. B., Castillo, T., Kongseree, N., Laignelet, B. et al. (1981). International cooperative testing on the amylase content of milled rice. Sturch/Stärke, 33, 157-162.

Kutos, T., Golob, T., Kac, M., \& Plestenjak, A. (2003). Dietary fibre content of dry and processed beans. Food Chemistry, 80, 231-235.

Lee. S. C., Prosky, L., \& DeVries. I. W. (1992). Determination of total, soluble and insoluble dietary fibre in loods - enzymatic-gravimetric method. MES-TRIS buffer: collaborative study. Jomnal of $A O A C$ International, 75, 395-416.

Mathres, J. C. (2002). Pulses and carcinogenesis: potential for the prevention of colon, breast and other cancers. British Journal of Nutrition, 88, S273-\$279

Ong, M. H., \& Blanxhard, J. M. V. (1995). Texture determinants in cooked parboiled rice. I: Rice starch anylase and the fine structure of amylopectine. Joumal of Cereal Scionce, 21, 251-260.

Park, J. K., Kim, S. S., \& Kim, K. O. (2001). Effect of milling ratio on sensory properties of cooked rice and on physical or chemical properties of milled and cooked rice. Cereal Chemistry, 78, $151-156$

Phirke, A. V., Chavan, H. K., Hadgam, S. J.. \& Salunkhe, D. K. (1982). Physical properties, chemical composition, cookability and solubilization of proteins of dry beans (Phasedus onlgaris L.). Journal of Legumes Reseurch, 5, 91-96.

Pujolà, M. Casañas. F., Bosch, L. Almirall, A., Sánchez, E., \& Nuez, F. (2004). Creaminess and chemical composition in dry beans (Phosecalus valgaris L.) the roles of protein and starch. In Fifth European conference on grain legumes. Conference Handbook. AEP. Dijon (p. 425).

Quenzer. N M., Fuman, V. L., \& Burns, E. E. (1978), Some factors affecting Pinto bean quality. Jomnal of Food Science, 43, 1059-1061.

Ramesh. M., Bhattacharya, K. R., \& Mitchell. J. R. (2000). Developments in understanding the basis of cooked-rice texture. Critical Reriews in Food Science and Natrition, 40, 449-460.

Rehman, Z. U.. Salariya. A. M. \& Zafar. S. I. (2001). Effect of processing on available carbohydrate content and starch digestibility of kidney beans (Phaseolus enlgaris L.). Food Chemistry, 73, 351 355.

Rehman, Z. U.. \& Shah. W. H. (2004). Domestic processing effects on some insoluble dietary fibre components of various food legumes. Food Chemisty, 8, 613-617

Rosin. P. M., Lajolo. F. M., \& Menezes, E. W. (2002). Measurement and characterization of dietary starches. Jommal of Foad Composition and Analysis, $15.367-377$. 
Santalla, M., De Ron. A. M.. \& Voysest, O. (2001). European bean market classes. In: M., Amurrio, M.. Santilla, A. M., De Ron (Eds.), Catalogue of bean genetic resources. Fundación Pedro Barrié de la MaZa/PHASELIEU-FAIR-PL-3463-MBG-CSIC (pp. 79-94).
SAS Institute (1985). SAS user glide: srarisics. Cary, NC: SAS Institute. Wang, C. R.. Chang, K. C.. \& Grafton. K. (1988). Canning quality evaluation of Pinto and Navy beans. Journal of Food Science, 53, $772-776$. 